\title{
Rediscovery, conservation status and taxonomic assessment of Melicope degeneri (Rutaceae), Kaua'i, Hawai'i
}

\author{
Kenneth R. Wood* \\ National Tropical Botanical Garden, Kalāheo, Hawai'i 96741, USA
}

\begin{abstract}
Melicope degeneri (B. Stone) T. Hartley \& B. Stone is endemic to the island of Kaua'i and is one of Hawai'i's rare members of the Rutaceae. Rediscovered in 1993 after not being documented for $67 \mathrm{yr}$, it is currently known from only 22 individuals. Data concerning its morphology, distribution, and ecological preferences are presented in this paper in order to contribute to the Global Strategy for Plant Conservation (GSPC) goals and to assist biologists and land managers in monitoring and protecting this species from extinction. A formal IUCN assessment of the species has been completed and is reported here as Critically Endangered (CR B2ab(iii,v); D).
\end{abstract}

KEY WORDS: Melicope degeneri - Rutaceae - Hawaiian Islands · Prevention of extinction . Distribution · Ecological preferences · IUCN Red List Category · Critically Endangered

\section{INTRODUCTION}

The genus Melicope Forst. \& Forst. (Rutaceae) comprises about 233 species which range from the Malagasy and Indo-Himalaya regions east to the Hawaiian and Marquesas Islands and south to New Zealand (Hartley 2001). The Hawaiian taxa were traditionally placed in the genus Pelea A. Gray, but were transferred to Melicope by Hartley \& Stone (1989). Melicope is among the largest flowering plant genera on the Hawaiian Islands (Wagner et al. 1990) and is exceeded only by Cyanea Gaudich. (Campanulaceae), with 76 endemic species (Givnish et al. 2009), and Cyrtandra Forst. \& Forst. (Gesneriaceae) with 59 (Wagner et al. 2001, Lorence \& Perlman 2007; see also http:// botany.si.edu/pacificislandbiodiversity/hawaiianflora/ query2.cfm). Hawaiian Melicope currently comprise 48 endemic species, 16 of which are federally listed as 'endangered', 3 are 'candidates' for listing and considered extremely rare, and 5 are thought to be extinct (Wagner et al. 1999, USFWS 2010). Other native genera of Rutaceae found in Hawai'i include Zanthoxylum L. and the Hawaiian endemic Platydesma H. Mann, each having 4 species and 1 infraspecific taxon.
Melicope degeneri (B. Stone) T. Hartley \& B. Stone is restricted to the island of Kaua'i and for many years was known only from a single collection made by Otto Degener in 1926 'along Kokee stream, Kaua'i, Hawai'i, in rain forest' (Degener 8531, Holotype [BISH], Isotypes [NY, SDC]). After not being observed for $67 \mathrm{yr}$ and considered 'possibly extinct' $M$. degeneri was rediscovered in 1993 (Wood 1998, 2007) and is currently known from 4 populations totaling 22 individuals and ranging in elevations between 747 and $1128 \mathrm{~m}$ $(2450$ and $3700 \mathrm{ft})$. The distribution and abundance of $M$. degeneri include the northwestern valleys of Pohakuao (1 tree) and Hanakoa (11 trees), an isolated site within the interior canyon region of Koai'e (1 tree), and a recently discovered population (2008) around the remote northern valley headwaters of Wainiha (9 trees) (Table 1, Fig. 1). These discoveries are the result of ongoing research conducted by the National Tropical Botanical Garden (NTBG) as part of their Pacific Island floristic inventories. Over the past few decades, this initiative resulted in numerous vascular plant discoveries, including 35 taxa thought to be extinct, in addition to 45 taxa previously unknown to science (K. R. Wood unpubl.). 
Table 1. Status of Melicope degeneri. All known sites, abundance, elevational range, last observation, and whether or not population is represented by seed collections

\begin{tabular}{|lcccc|}
\hline Known sites & No. of ind. & Elevation & Last obs. & Seed coll. \\
\hline Koke‘e Stream & Unknown & $\sim 1035 \mathrm{~m}(3400 \mathrm{ft})$ & Jun 1926 & No \\
Pohakuao & 1 & $1128 \mathrm{~m}(3700 \mathrm{ft})$ & Feb 1993 & No \\
Hanakoa & 11 & $1128 \mathrm{~m}(3700 \mathrm{ft})$ & Jan 2011 & Yes \\
Koai'e & 1 & $930 \mathrm{~m}(3050 \mathrm{ft})$ & Sep 2006 & Yes \\
Wainiha & 9 & $747-792 \mathrm{~m}$ & Oct 2009 & Yes \\
& & $(2450-2600 \mathrm{ft})$ & & \\
\hline
\end{tabular}

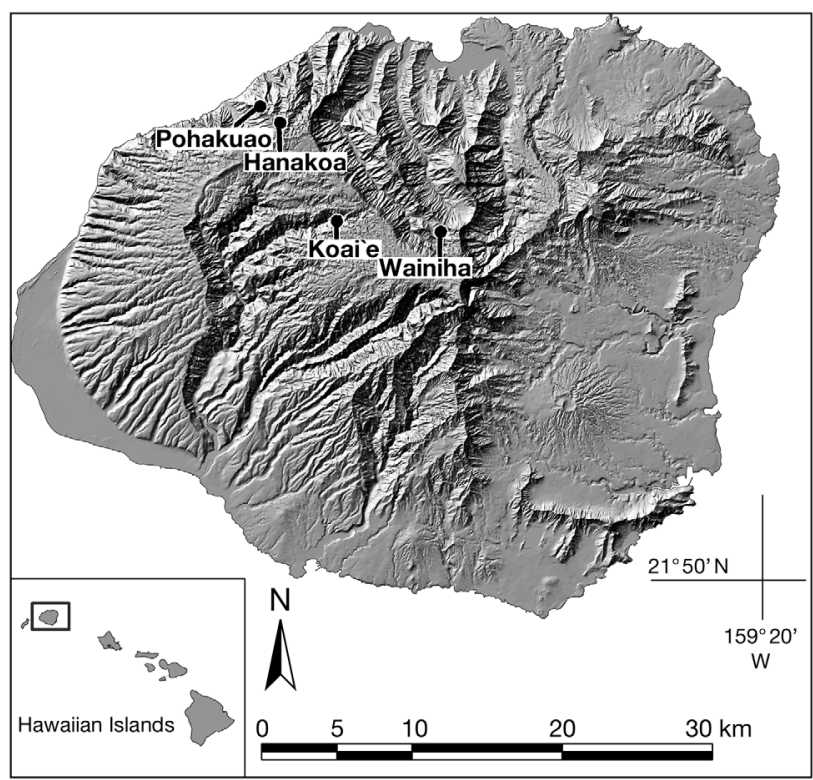

Fig. 1. Shaded relief map of Kaua'i, Hawai'i showing current distribution of Melicope degeneri ( ) in the valleys of Pohakuao, Hanakoa, Koai'e, and Wainiha

\section{MATERIALS AND METHODS}

Intensive biological field surveys were conducted on the island of Kaua'i by the author from 1988 to the present with strict adherence to all relevant state, national and international legislation. General objectives were to (1) locate populations of rare Hawaiian plant taxa, (2) collect seeds and/or cuttings for propagation, (3) disseminate data concerning their distribution and abundance, (4) describe ecological components and habitats, (5) evaluate threats, (6) photograph vegetation types and specific plants, and (7) make recommendations for managing regions that contain high levels of floristic diversity. Access to locations with difficult topography was facilitated by helicopter transport. Herbarium voucher collections were made to document common and rare plant taxa during surveys. Data for herbarium specimens were entered into the PTBG herbarium database (cu- rated at the NTBG, Kalāheo, Hawai'i). Latitude and longitude coordinates were recorded by GPS using the North America Datum 1983 (NAD 83).

Measurements for the species description of Melicope degeneri were taken from herbarium specimens collected from wild source individuals of Melicope degeneri discovered and monitored on Kaua'i between 1993 and present, and housed at the PTBG herbarium, in addition to the type collection at BISH herbarium, Honolulu, Hawai'i (see 'Results: Material examined'). Plant names and authors of Hawaiian dicots and monocots follow Wagner et al. (1990), Hawaiian pteridophytes follow Palmer (2003), and acronyms for herbaria follow Index Herbariorum (http://sweetgum.nybg.org/ih/).

\section{RESULTS}

\section{Description of Melicope degeneri}

When Melicope degeneri was originally described by B. C. Stone (1966), no flowers were available. With additional voucher material collected and housed at PTBG, a more expanded taxonomic description is warranted. Contrary to its original description as a shrub, M. degeneri is amongst the largest of Hawaiian Melicope and can reach heights of up to $11 \mathrm{~m}$ (Fig. 2). Morphologically, the leaves and habit of $M$. degeneri appear most similar to those of $M$. puberula which is a sympatric species. However, $M$. degeneri can be easily differentiated in the field by its cuboid fruit (Fig. 3) with glabrous exocarp and endocarp, which contrast with the lobed carpels (megacarp) of $M$. puberula. The latter are connate at approx. half their length and have a puberulent exocarp and sparsely short-villous endocarp.

Melicope degeneri (B. Stone) T. Hartley \& B. Stone, Taxon 38:119-123, 1989; Pelea degeneri B. C. Stone, Bishop Mus. Occ. Pap. 23 (10): 161, 1966. - TYPE: U.S.A. Hawaiian Islands, Kaua'i: along Kokee stream in rainforest, 30 Jun 1926, Otto Degener 8531 (Holotype: $\mathrm{BISH}$, Isotypes: NY, SDC).

Medium-sized trees 4-11 m tall, with trunks up to $27 \mathrm{~cm}$ diameter, bark reddish brown, new growth densely yellowish-brown tomentose, young branches tomentose, becoming glabrate with age. Leaves opposite, coriaceous, elliptic to elliptic-obovate, $6-20.5 \mathrm{~cm}$ long, 2-8.5 cm wide, primary lateral veins usually 12-20 pairs, inconspicuous, upper surface glabrate, lower surface villous, especially along midrib, apex rounded or slightly emarginate, base broadly cuneate to rounded, petioles $15-30 \mathrm{~mm}$ long, densely short 


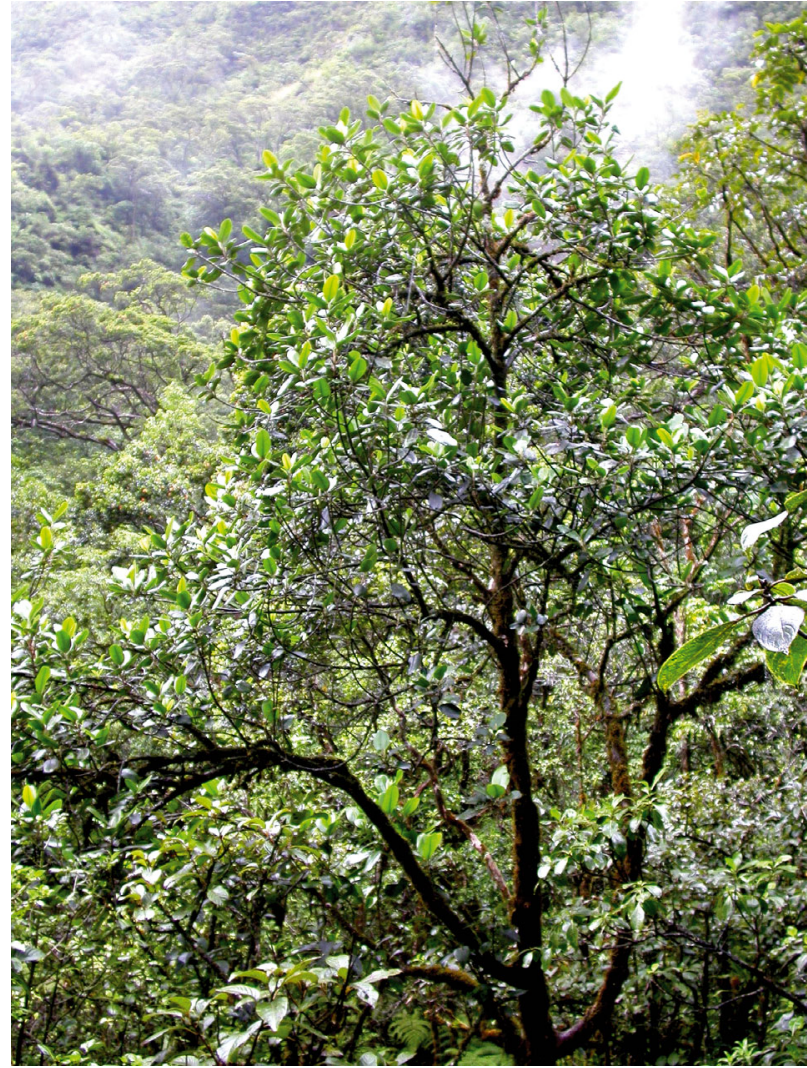

Fig. 2. Growth habit of Melicope degeneri in Wainiha Valley, Kaua'i

villous. Flowers 3-10 in yellowish brown tomentose axillary cymes up to $5.5 \mathrm{~cm}$ long, peduncles up to $2 \mathrm{~cm}$ long, pedicels 3-11 mm long, bracteoles deltate ca. $1 \mathrm{~mm}$ long, staminate flowers unknown, pistillate flowers with sepals deltate, $3 \mathrm{~mm}$ long, appressed puberulent, petals yellow-green, deltate, 4.5-5 mm long, minutely appressed puberulent, nectary disk glabrous, stamens rudimentary, ovary glabrous, ca. 2.0-2.2 mm wide, style slender, ca. $2 \mathrm{~mm}$ long, glabrous. Capsules cuboid, 7-9 mm long, 7-12 mm wide, carpels connate, exocarp and endocarp glabrous. Seeds ca. $4.5 \mathrm{~mm}$ long.

\section{Material examined}

KAUA'I: along Koke'e stream in rainforest, 30 Jun 1926, Otto Degener 8531 (BISH, CATH, NY); Hanalei District, Pohakuao, 17 Feb 1993, 3700 ft, K. R. Wood 2384 (PTBG, BISH, US); Hanalei District, Hanakoa, 29 Aug 1998, 3700 ft, K. R. Wood 7439 (CANB, NY, PTBG, US); loc. id., 29 Aug 1998, $3700 \mathrm{ft}, K . R$. Wood 7440 (CANB, PTBG); loc. id., 29 Aug 1998, 3700 ft, $K$. R. Wood 7441 (CANB, MO, NY, PTBG, US); loc. id., 29

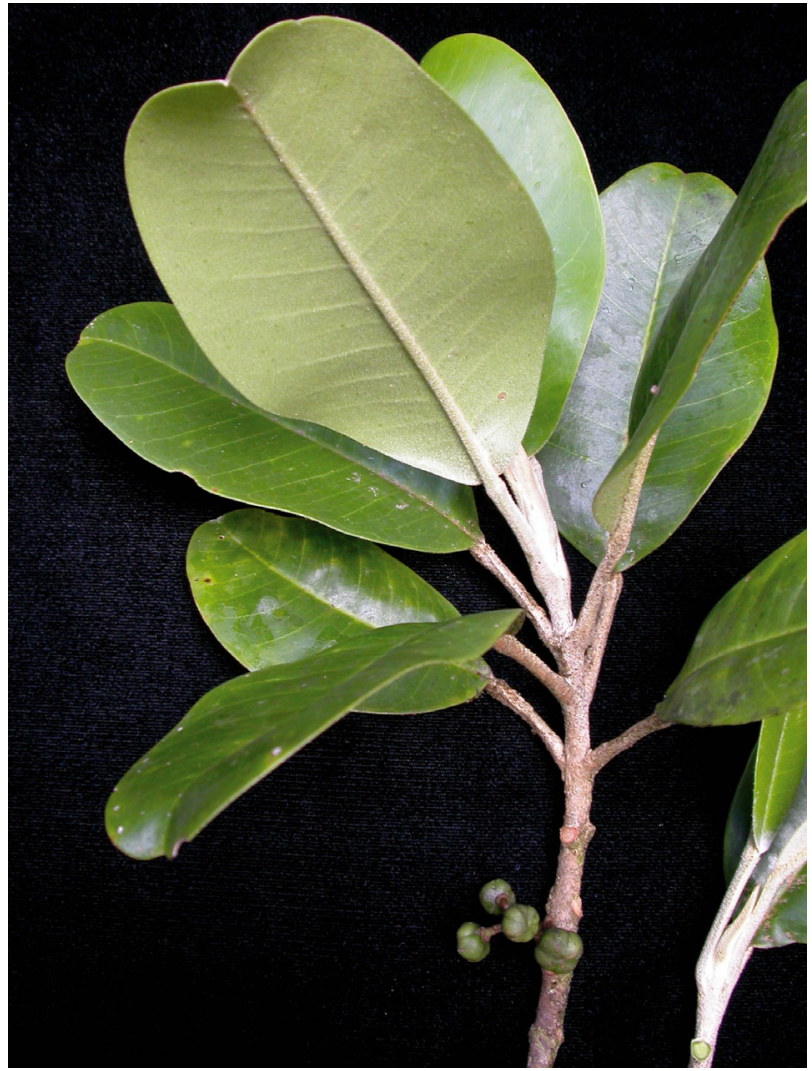

Fig. 3. Fruiting branch of Melicope degeneri showing cuboid capsules

Aug 1998, 3700 ft, K. R. Wood 7445 (PTBG); loc. id., 29 Aug 1998, 3700 ft, K. R. Wood 7446 (PTBG, US); loc. id., 25 Jan 1995, K. R. Wood 3966 (BISH, K, MO, NY, P, PTBG, US, WU), loc. id., 11 Nov 1995, Perlman et al. 15,123 (BISH, F, K, MO, NY, PTBG, US, WU); loc id., 18 Aug 2004, Perlman \& Tangalin 19287 (BISH, PTBG, US); loc id., 18 Aug 2004, Perlman \& Tangalin 19288 (BISH, PTBG); Koai'e Canyon, 3 Feb 1999, 3050 ft, $K$. R. Wood 7662 (PTBG, US), loc. id., 17 Sep 2006, K. R. Wood \& N. Tangalin 12137 (PTBG); Wainiha, 16 Jun 2008, 747 m, K. R. Wood 13102 (PTBG); loc. id., 10 Sep 2008, 768 m, K. R. Wood 13255 (PTBG); loc. id., 11 Sep 2008, 792 m, K. R. Wood 13272a (PTBG).

\section{Regional habitat descriptions of Melicope degeneri within its current range}

Melicope degeneri is apparently restricted to forest habitats dominated by Metrosideros Banks ex Gaertn. (Myrtaceae). The forest community around the Pohakuao and Hanakoa populations is a Metrosideros montane wet forest with sections co-dominated by Cheirodendron Nutt. ex Seemann. The Koai'e site is a 
transitional Metrosideros montane mixed mesic to wet forest, and the Wainiha population occurs in a lowland Metrosideros wet forest. The following regional descriptions further define the associated plant components that co-exist with $M$. degeneri at these sites and can be used as a guide to conservation biologists interested in re-establishing populations of $M$. degeneri within appropriate habitats.

\section{Pohakuao}

A single pistillate tree of Melicope degeneri was documented below Alealau peak in Pohakuao Valley. This location lies just beyond the northwest corner of Kaua'i's Hono O Na Pali Natural Area Reserve (NAR) and on the very steep Pohakuao side of the dividing ridge separating Kalalau Valley from Pohakuao (Fig. 1). Although the herbarium specimen (Wood 2384 ) indicates that the collection was made on the Kalalau side of the dividing ridge, this was an erratum and the actual location should read Pohakuao. This individual has not been reassessed since 1993 because of the very steep and difficult access. The region has a $50 \%$ closed canopy and the habitat can be described as a Metrosideros polymorpha Gaudich.-Cheirodendron spp. montane wet forest with a rich pteridophyte understory of Dicranopteris linearis (Burm. f.) Underw., Diplazium sandwichianum (C. Presl) Diels, and several species of Sadleria Kaulf. Associated understory trees include Labordia degeneri Sherff, Myrsine linearifolia Hosaka, and Xylosma hawaiiensis Seem. Terrestrial shrubs and sedges are Broussaisia arguta Gaudich., Vaccinium dentatum Sm., and Carex meyenii Nees.

The Pohakuao $M$. degeneri is $5 \mathrm{~m}$ tall and occurs at around $1128 \mathrm{~m}$ (3700 ft) elevation. Its habit is robust with a single trunk of $15 \mathrm{~cm}$ diameter at breast height $(\mathrm{DBH})$, with its main branching beginning at ca. $2 \mathrm{~m}$ height, and with 4 to 5 additional secondary branches supporting 7 to 15 terminal branchlets each.

Threats to the Pohakuao ecosystem include habitat degradation by feral goats Capra hircus L. and pigs Sus scrofa L., predation of seeds by black rats Rattus rattus L. and Polynesian rats $R$. exulans Peale, extinction as a result of natural catastrophes (e.g. landslides, hurricanes and severe storms, flash floods, fallen limbs that crush young trees, and fire), and competition with non-native plant taxa such as Paspalum urvillei Steud. and Rubus argutus Link.

\section{Hanakoa}

The Hanakoa population of Melicope degeneri is currently known from 11 individuals and was moni- tored as recently as January 2011 (Fig. 1). Seeds have been collected from numerous individuals since its discovery in 1995. Eight trees are pistillate, and the remaining 3 are of unknown sex. This region is part of the Hono O Na Pali NAR and is referred to by local botanists as the upper Hanakoa drainage. The trees occur at a distance of around $1250 \mathrm{~m}(4100 \mathrm{ft})$ to the north of a well-known site called Pihea Peak, at an elevation of $1128 \mathrm{~m}(3700 \mathrm{ft})$. The canopy is 50 to $70 \%$ closed, and the plant community is a Metrosideros montane wet forest with riparian vegetation. Numerous species of Melicope occur in this area including $M$. anisata (H. Mann) T. G. Hartley \& B. C. Stone, M. clusiifolia (A. Gray) T. G. Hartley \& B. C. Stone, M. peduncularis (H. Lév.) T. G. Hartley \& B. C. Stone, and M. puberula (H. St. John) T. G. Hartley \& B. C. Stone. Additional trees and shrubs include several species of Cheirodendron, Cyanea fissa $(\mathrm{H}$. Mann) Hillebr., C. rivularis Rock, Dubautia knudsenii Hillebr., Ilex anomala Hook. \& Arn., Kadua affinis DC., K. cordata Cham. \& Schltdl., K. foggiana (Fosberg) W.L. Wagner \& Lorence, Perrottetia sandwicensis A. Gray, Pipturus ruber A. Heller, Psychotria hexandra H. Mann, Trematolobelia kauaiensis (Rock) Skottsb., and Xylosma hawaiiensis. Other genera in the area include Bobea Gaudich., Coprosma Forst. \& Forst., Elaeocarpus L., Pleomele Salisb., Pouteria Aubl., and Scaevola L. Associated ferns include Dicranopteris linearis, Diplazium sandwichianum, Sticherus owhyhensis (Hook.) Ching, and several tree fern species of Cibotium Kaulf. and Sadleria. The sedge Machaerina angustifolia (Gaudich.) T. Koyama is very common in the area.

Ten trees were originally documented during the discovery of the Hanakoa population in 1995, 2 of which have since died. One tree appeared to have been killed by a flash flood and the other (above the stream banks) died of unknown cause. Subsequent research in the surrounding area has revealed 3 additional trees of Melicope degeneri, thus making a total of 11 individuals. The trees range between 4 and $11 \mathrm{~m}$ in height, have reddish-brown trunks with 2 to 4 major branches, each with 5 to 9 branchlets. The new growth of leaves is densely yellowish-brown tomentose. Mature leaves are shiny dark green on the upper surface and paler below with yellow-brown villous nerves. The substrate is a fine brown soil with leaf litter.

Threats to Hanakoa include habitat degradation by pigs, Polynesian and black rats, extinction as a result of natural catastrophes, and competition with non-native plant taxa such as Cyperus meyenianus Kunth, Bryophyllum pinnatum (Lam.) Oken, Erigeron karvinskianus DC., Hedychium gardnerianum Ker Gawl., Paspalum urvillei, Rubus argutus, and $R$. rosifolius Sm. 
Koai'e

A single pistillate individual of Melicope degeneri occurs in Koai'e Stream, a tributary of the Waimea Canyon which lies within the isolated interior of Kaua' $i$ (Fig. 1). The site has a 50 to $70 \%$ closed canopy and the plant community is a transitional Metrosideros mixed mesic to wet forest with some remnants of Diospyros L. forest nearby. It is located on the southeast side of the main stream, on the north-facing banks of a small side gulch. Associated tree species include Antidesma platyphylla H. Mann, Bobea timonioides (Hook.f.) Hillebr., Cheirodendron fauriei Hochr., Claoxylon sandwicensis Müll. Arg., Dodonaea viscose Jacq., Dubautia microcephala Skottsb., Ilex anomala, Myrsine linearifolia, Pipturus ruber, Pleomele aurea (H. Mann) N.E. Br., Pouteria sandwicensis (A. Gray) Baehni \& O. Deg., Pritchardia minor Becc., Tetraplasandra kavaiensis (H. Mann) Sherff, and Zanthoxylum dipetalum $\mathrm{H}$. Mann. Understory ferns in the area are Dicranopteris linearis, Diplazium sandwichianum, Dryopteris fuscoatra (Hillebr.) W.J. Rob., Elaphoglossum aemulum Skottsb., and Microlepia strigosa (Thunb.) C. Presl.

The Koai'e Melicope degeneri occurs at around $930 \mathrm{~m}(3050 \mathrm{ft})$ elevation. It is $4 \mathrm{~m}$ tall, moderately branched, with a $12 \mathrm{~cm}$ diameter trunk at the base. Ancillary collections of leaf and flower material were placed in silica and $70 \%$ ethanol for DNA sequencing and morphological studies. Seeds were collected at the time of discovery in 1999, and subsequently in 2006. There may be other trees of $M$. degeneri in the region, as there is fine habitat in the surrounding area, and seed production most likely indicates successful pollination from a staminate individual.

Threats to the Koai'e region include habitat degradation by goats, pigs, Polynesian and black rats, extinction as a result of natural catastrophes, and competition with non-native plant taxa such as Bryophyllum pinnatum, Erigeron karvinskianus, Lantana camara L., Paspalum urvillei, Rubus argutus, and Setaria parviflora (Poir.) Kerguélen.

\section{Wainiha}

The Wainiha population of Melicope degeneri is known from 9 individuals located around the upper northeastern fork of the Wainiha River (Fig. 1). Two trees are confirmed pistillate and the others are of unknown sex. The canopy is $50-70 \%$ closed and dominated by Metrosideros forest reaching heights of 8-12 $\mathrm{m}$. The trees range in elevation between 747 and $792 \mathrm{~m} \mathrm{(2450}$ and $2600 \mathrm{ft}$ ). The understory is dominated by trees of Antidesma platyphyllum along with mixed wet forest associates such as Broussaisia arguta,
Cheirodendron forbesii (Sherff) Lowry, Coprosma waimeae Wawra, Cyrtandra cyaneoides Rock, C. oenobarba H. Mann, Dubautia knudsenii, Labordia tinifolia A. Gray, Perrottetia sandwicensis, Psychotria hexandra, Syzygium sandwicensis (A. Gray) Nied., Tetraplasandra kavaiensis, and T. oahuensis (A. Gray) Harms. A rich bryophyte understory prevails along with an abundance of ferns including the very common Dicranopteris linearis and Diplazium sandwichianum, along with species of Adenophorus Gaudich., Asplenium L., Athyrium Roth., Cibotium, Coniogramme Fée, Deparia Hook. \& Grev., Elaphoglossum Schott ex J. Sm., Pneumatopteris Nakai, and Sadleria.

The Wainiha Melicope degeneri are 5-9 $\mathrm{m}$ tall, $10-27 \mathrm{~cm}$ diameter at their bases and are moderately branched. Stems are brown, and the leaves are dark green with tan-brown scurf on the young leaves. Seeds for conservation were collected from 2 individuals in this population during 2008 and are being cultivated by the NTBG.

Threats to the Wainiha region include habitat degradation by pigs, Polynesian and black rats, extinction as a result of natural catastrophes, and competition with non-native plant taxa such as Andropogon glomerata (Walter) Britton, Sterns \& Poggenb., Buddleia asiatica Lour., Clidemia hirta (L.) D. Don, Cyperus meyenianus, Erigeron karvinskianus, Hedychium gardnerianum, Juncus planifolius R. Br., Pluchea carolinensis (Jacq.) G. Don, Psidium guajava L., and Sphaeropteris cooperi (Hook. ex F. Muell.) R.M. Tryon.

\section{Conservation status: Critically Endangered}

When evaluated using the World Conservation Union (IUCN) criteria for extinction risk (IUCN 2001), Melicope degeneri falls into the Critically Endangered (CR) Red List category, which designates this species as facing the highest risk of extinction in the wild. Melicope degeneri meets the IUCN criteria in having an area of occupancy of $<10 \mathrm{~km}^{2}$, severely fragmented individuals, a decline in the quality of habitat, a continuing decline inferred for the number of mature individuals, and a population size $<50$ mature individuals (Table 1 ). My formal evaluation can be summarized by the following IUCN hierarchical alphanumeric numbering system of criteria and subcriteria as CR B2ab(iii,v); D. Melicope degeneri is also listed by the US Fish \& Wildlife Service as 'endangered' under the Endangered Species Act of 1973.

\section{Summary of threats}

Numerous factors that are threatening many of Hawai'i's rare taxa have put Melicope degeneri into 
the Critically Endangered category. Known threats to this species include habitat degradation and destruction by feral goats and pigs; predation of seeds by rats; extinction as a result of natural catastrophes; competition with non-native plant taxa such as Andropogon glomerata, Bryophyllum pinnatum, Buddleia asiatica, Clidemia hirta, Cyperus meyenianus, Erigeron karvinskianus, Hedychium gardnerianum, Juncus planifolius, Lantana camara, Paspalum urvillei, Pluchea carolinensis, Psidium guajava, Rubus argutus, R. rosifolius, and Sphaeropteris cooperi, all of which possess the ability to spread rapidly and cover effectively large areas in the forest understory (Smith 1985); and reduced reproductive vigor as the result of few remaining individuals, many of which are isolated from each other.

\section{DISCUSSION}

Target 2 of the Global Strategy for Plant Conservation (GSPC) as implemented through the Convention on Biological Diversity (CBD) called for a preliminary assessment of the conservation status of all known plant species by 2010 (GSPC 2002) and the present paper contributes, in its small way, to this ambitious goal, although a more realistic time frame needs to be proposed. The main objective of GSPC is to halt the continuing loss of plant diversity and to encourage the ecosystem approach toward conservation. The lack of biotic regional data has become a serious barrier to the conservation and sound management of the earth's remaining natural ecosystems.

The magnificent flora of Kaua'i is unparalleled in the archipelago, including 253 single island endemic taxa (SIE) that occur nowhere else on earth (K. R. Wood unpubl.). Rigorous botanical research conducted over the past few decades by staff of the NTBG has contributed 28 new taxa to the flora of Kaua'i (Lammers \& Lorence 1993, Wagner et al. 1994, 2001, Lorence \& Wagner 1995, 1996, Lorence 1996, Carr \& Lorence 1998, Wagner \& Lorence 1998, Wagner 1999, Wood \& Wagner 1999, Lowry \& Wood 2000, Lorence \& Gemmill 2004, Wood et al. 2007, Lorence et al. 2010) increasing the island's previously known SIE level by $12.5 \%$. Many of those species represent endemic genera, and all of them are on the brink of extinction. Kaua' $i$ remains the most floristically rich of all the Hawaiian Islands, yet at the same time has the greatest number of federally listed endangered taxa, totaling 138 (USFWS 2010).

Tropical islands are particularly vulnerable to human disturbance, including habitat loss and impact of invasive non-native species which disrupt ecosystem functions. This is especially true on Kaua'i, and much work is needed to better understand and quickly disseminate information on the ecology and distribution of threatened species so that protected habitats can be established and managed, and conservation collections can be expedited. Existing impediments to this goal are limited funds, a scarcity of trained biologists, and an overabundance of endangered taxa, compounded by stochastic events that can easily destroy species that are few in number or known from single populations. A case in point is Melicope quadrangularis (H. St. John \& E. Hume) T. Hartley \& B. Stone, a Kaua'i endemic and close relative to $M$. degeneri. $M$. quadrangularis was known only from the holotype collection made in 1909, rediscovered by the author of the present study in May 1991 (Lorence et al. 1995), and subsequently destroyed the following year (September 1992) by Hurricane Iniki. Unfortunately the author of the present study failed to monitor and collect seeds, thinking there was adequate time to conserve $M$. quadrangularis (Wood 2000).

Failure to monitor and collect germplasm of rare taxa can result in extinction. Although all populations of Melicope degeneri should be monitored for seed and protected from threats, the most practical site for seed collection is the Hanakoa population, which can be easily accessed via the Kokee Pihea Trail. This is also the largest colony known. The Wainiha population, although much more isolated and requiring helicopter support for access, will be the most realistic site at this time for building up population numbers of $M$. degeneri since it lies within an actively managed watershed preserve. Following the ecosystem approach, a strategic fence is currently being built by The Nature Conservancy of Hawai'i (TNCH), in partnership with the Kaua'i Watershed Alliance (KWA) with the intention to ultimately protect 7050 acres $\left(\sim 28.5 \mathrm{~km}^{2}\right)$ of prime watershed in Wainiha and the adjacent Alaka'i plateau from the destructive presence of non-native feral ungulates, particularly pigs. A total of 296 other native plant taxa, 104 of which are Kaua'i endemics, also occur within the preserve, in association with some of the finest remaining populations of Kaua'i's avifauna and native insect populations (Wood 2007b, 2009, Wood \& Holmes 2008). This conservation initiative will need much support for success, as it is in its early stage, is vulnerable to numerous invasive plant and animal species, and has a highly variable physical geography that is difficult to access.

Each species is a crowning achievement of evolution, extending back many hundreds of thousands - or even millions of years. Concerning Melicope on Kaua'i, 3 species are currently considered extinct, as there are no known individuals remaining. It is recommended that efforts be made to locate them. These 
include M. macropus (Hillebr.) T. Hartley \& B. Stone, which was observed in the Kaholuamanu region in 1895 and 1910, also on the steep slopes of Kalalau in 1987, and last documented around the Honopu region of Koke'e in 1991; M. nealae (B. Stone) T. Hartley \& B. Stone, which was last observed in 1979 in the Honopu region of Koke'e, and also observed around Kaholuamanu in 1909, and above Kumuwela in 1960; and the previously mentioned $M$. quadrangularis, only known from the Wahiawa region and last observed in 1991 (Wood in press). It is further recommended that research be conducted on Melicope to better understand their breeding systems, life cycles, and plant-animal relationships. Many endemic plants have co-evolved with endemic insects and birds and require each other for survival, and the rarity or absence of pollinators and dispersers may also lead to extinction.

Acknowledgements. Gratitude goes to the staff of the National Tropical Botanical Garden (NTBG), The Nature Conservancy of Hawai'i, the Bernice P. Bishop Museum, and the Smithsonian Institution for their dedication and long time support of botanical research in Hawai'i and the Pacific. For their dedication in facilitating conservation collections of Melicope degeneri and numerous other endangered Hawaiian plant taxa, a special recognition goes out to S. Perlman (NTBG) and W. Kishida, Kaua'i Coordinator for the Plant Extinction Prevention Program, in association with the Pacific Cooperative Studies Unit and Research Corporation of the University of Hawai'i, and funded by the Department of Land \& Natural Resources, Division of Forestry and Wildlife and the US Fish \& Wildlife Service.

\section{LITERATURE CITED}

Carr GD, Lorence DH (1998) A new species of Dubautia (Asteraceae-Madiinae) from Kaua'i, Hawaiian Islands. Novon 8:4-7

Givnish TJ, Millam KC, Mast AR, Paterson TB and others (2009) Origin, adaptive radiation, and diversification of the Hawaiian lobeliads (Asterales: Campanulaceae). Proc Biol Sci 276:407-416

GSPC (Global Strategy for Plant Conservation) (2002) Convention on Biological Diversity, Montreal. Available at http://intranet.iucn.org/webfiles/doc/SSC/SSCwebsite/ Plants/global_strategy.pdf (accessed August 11, 2010)

Hartley TG (2001) On the taxonomy and biogeography of Euodia and Melicope (Rutaceae). Allertonia 8(1)

Hartley TG, Stone BC (1989) Reduction of Pelea with new combinations in Melicope (Rutaceae). Taxon 38:119-123

IUCN (2001) IUCN Red List Categories and Criteria Version 3.1. IUCN Criteria Review Working Group. IUCN, Cambridge

Lammers TG, Lorence DH (1993) A new species of Cyanea (Campanulaceae: Lobelioideae) from Kaua'i, and the resurrection of C. Remyi. Novon 3:431-436

Lorence DH (1996) A new species of Nototrichium (Amaranthaceae) from Kaua'i, Hawaiian Islands. Novon 6:64-67

Lorence DH, Gemmill C (2004) Pritchardia flynnii (Arecaceae), a new endemic species from Kaua'i, Hawaiian Islands. Novon 14:185-189
Lorence DH, Perlman S (2007) A new species of Cyrtandra (Gesneriaceae) from Hawai'i, Hawaiian Islands. Novon 17:357-361

Lorence DH, Wagner WL (1995) Another new, nearly extinct species of Hibiscadelphus (Malvaceae) from the Hawaiian Islands. Novon 5:183-187

> Lorence DH, Wagner WL (1996) A new species of Chamaesyce section Sclerophyllae (Euphorbiaceae) from Kaua'i. Novon 6:68-71

Lorence DH, Flynn T, Wagner WL (1995) Contributions to the flora of Hawai'i. III. New additions, range extensions, and rediscoveries. Bishop Mus Occas Pap 41:19-58

Lorence DH, Wagner WL, Laidlaw WG (2010) Kadua haupuensis (Rubiaceae: Spermacoceae), a new endemic species from Kaua'i, Hawaiian Islands. Brittonia 62: 137-144

Lowry PP II, Wood KR (2000) A new, threatened species of Tetraplasandra (Araliaceae) from Kaua'i, Hawaiian Islands, and notes on its conservation status. Novon 10: 40-44

Palmer DD (2003) Hawai`i's ferns and fern allies. University of Hawai i Press, Honolulu, HI

Smith CW (1985) Impact of alien plants on Hawai'i's native biota. In: Stone CP, Scott JM (eds) Hawai'i's terrestrial ecosystems: preservation and management. Cooperative National Park Resources Studies Unit, University of Hawai'i, Manoa, HI, p 180-250

Stone BC (1966) Studies in Hawaiian Rutaceae, VII. A conspectus of species and varieties and some further new taxa in the genus Pelea A. Gray. Bishop Mus Occas Pap 23: $147-162$

USFWS (United States Fish and Wildlife Service) (2010) Endangered and threatened wildlife and plants; determination of Endangered status for 48 species on Kaua'i and designation of critical habitat. Fed Regist 75:18959-19008

- Wagner WL (1999) A new species of Hawaiian Phyllostegia (Lamiaceae) from Kaua'i and recognition of a Wai'anae mountain, O'ahu endangered variety of Phyllostegia parviflora. Novon 9:280-283

Wagner WL, Lorence DH (1998) A new, dioecious species of Hedyotis (Rubiaceae) from Kaua'i, Hawaiian Islands, and the taxonomy of Hedyotis schlechtendahliana resolved. Novon 8:311-317

Wagner WL, Herbst DR, Sohmer SH (1990) Manual of the flowering plants of Hawai'i. University of Hawai'i Press \& Bishop Museum Press, Honolulu

Wagner WL, Weller SG, Sakai AK (1994) Description of a rare new cliff-dwelling species from Kaua'i, Schiedea attenuata (Caryophyllaceae). Novon 4:187-190

Wagner WL, Bruegmann M, Herbst DR, Lau JQ (1999) Hawaiian vascular plants at risk: 1999. Bishop Mus Occas Pap 60:1-64

Wagner WL, Wood KR, Lorence DH (2001) A new species of Cyrtandra (Gesneriaceae) from Kaua'i, Hawaiian Islands. Novon 11:146-152

Wood KR (1998) The distribution, habitat, ecology, and conservation of Melicope degeneri (Rutaceae) from Kaua'i, Hawai'i-with a description of its flowers and habit. Biological report. National Tropical Botanical Garden, Kalāheo, $\mathrm{HI}$

Wood KR (2000) Biogeographical research and conservation. Three Melicope survey: Melicope degeneri, M. knudsenii, \& M. quadrangularis. USFWS Grant No. 1448-1220099-M090. US Fish \& Wildlife Service, Washington, DC

Wood KR (2007a) Taxonomic notes on Melicope degeneri (Rutaceae). Biological report. National Tropical Botanical Garden, Kalāheo, HI 
Wood KR (2007b) Notes on the flora of Wainiha and Alaka'i, Kaua'i, Hawai'i. Biological report prepared for The Nature Conservancy and the Kaua'i Watershed Alliance, Lìhue, $\mathrm{HI}$

Wood KR (2009) Further notes on the flora of Wainiha, Kaua'i, Hawai'i, with comments on proposed strategic fence. Biological report prepared for The Nature Conservancy and the Kaua'i Watershed Alliance, Līhue, HI

Wood KR (in press) Possible extinctions, rediscoveries and new plant records within the Hawaiian Islands. Bishop Mus Occas Pap

Wood KR, Holmes N (2008) Observations and recommendations concerning the Alaka'i protective fence project, Waimea and Wainiha Ahupua'a, Waimea and Hanalei

Editorial responsibility: Dave Roberts, Canterbury, UK
District, Island of Kaua'i TMK: [4] 5-8-001:001 \& 1-4001:003. Biological survey prepared for the Kaua'i Watershed Alliance and The Nature Conservancy, Lìhue, HI, December 2007 and July 2008 Available at http://hawp. org/_library/documents/news-and-announcements/eastal akaiprotecticefenceprojectbiologicalsurveyfinal10-08.pdf

Wood KR, Wagner WH (1999) Doryopteris angelica sp. nov. In: Wagner WH, Wagner FS, Hobdy RW, Palmer DD (eds) Taxonomic notes on the Pteridophytes of Hawai'i II. Contr Univ Mich Herb 22:147-149

Wood KR, Wagner WL, Motley TJ (2007) Labordia lorenciana (Loganiaceae): a new critically endangered species from Kaua'i, Hawaiian Islands with comments on its conservation. Syst Bot 32:195-199

Submitted: August 13, 2010; Accepted: March 14, 2011 Proofs received from author(s): April 28, 2011 